\title{
Evaluation of some traditional medicinal plants: phyto- chemical profile, antibacterial and antioxidant potentials
}

\author{
ARZU UCAR TURKER ${ }^{1 *}$ ARZU BIRINCI YILDIRIM ${ }^{2}$, ISA TAS $^{1}$, ERVA OZKAN $^{1}$, \\ HAKAN TURKER ${ }^{1}$
}

${ }^{1}$ Department of Biology, Faculty of Arts and Sciences, Bolu Abant Izzet Baysal University, Bolu, Turkey ${ }^{2}$ Department of Field Crops, Faculty of Agriculture and Natural Sciences, Bolu Abant Izzet Baysal University, Bolu, Turkey

\begin{abstract}
Bioassays provide an authentication of the traditional knowledge of medicinal plants. Antibacterial, antioxidant and phenolic content of nine medicinal plants (Achillea millefolium, Prunella vulgaris, P. laciniata, Lythrum salicaria, Epilobium angustifolium, E. hirsutum, Pedicularis comosa, Agrimonia eupatoria and Verbena officinalis) were investigated in connection with folkloric usages. Aerial parts of nine plant species were extracted with water and methanol $(\mathrm{MeOH})$. Disc diffusion method was performed to evaluate the antibacterial activity of the extracts against ten pathogenic bacteria. Antioxidant activity was determined by using 2,2-diphenyl-1picrylhydrazil (DPPH) radical photometric assay. Total phenolic and flavonoid content were investigated by using Folin-Ciocaltaeu and aluminum chloride $\left(\mathrm{AlCl}_{3}\right)$ colorimetric method, respectively. Quantitative analysis of phenolic constituents of nine plants species were performed by high performance liquid chromatography-diode array detector (HPLC-DAD) via chosen ten phenolic standards (gallic acid monohydrate, caffeic acid, rutin hydrate, luteolin-7-O- $\beta$-D glucoside, kaempferol, rosmarinic acid, myricetin, quercetin, coumarin and apigenin). E. hirsutum showed the best antibacterial activity against gram-positive bacteria (S auerus, S. epidermidis and $S$. pyogenes). L. salicaria also demonstrated strong and broad spectrum antibacterial activity. P. laciniata, L. salicaria and E. angustifolium showed potent antioxidant activity. The highest phenolic and flavonoid content was observed with E. hirsutum and A. millefolium, respectively. L. salicaria also had very high amount of total phenol and flavonoid content. HPLC-DAD analysis displayed that $P$. laciniata and A. eupatoria were the best sources of rosmarinic acid. Furthermore, V. officinalis and $P$. vulgaris also had remarkable amount of rutin. This study revealed the scientific rationale behind the traditional knowledge of the tested plants. Consistent with traditional usages, the most prominent plants were L. salicaria, E. hirsutum and E. angustifolium in regard to strong antibacterial and antioxidant potentials. These plants may be proper natural sources with potential applications in pharmaceutical and food industry.
\end{abstract}

Keywords Antibacterial; Antioxidant; Flavonoid; HPLC; Phenol.

To cite this article: TURKER AU, YILDIRIM AB, TAS I, OZKAN E, TURKER H. Evaluation of some traditional medicinal plants: phytochemical profile, antibacterial and antioxidant potential. Rom Biotechnol Lett. 2021; 26(2): 2499-2510. DOI: 10.25083/rbl/26.2/2499.2510

ARZU UCAR TURKER, Prof. Dr., Bolu Abant Izzet Baysal University, Department of Biology, 14280 Bolu, Turkey

E-mail: turker_a@ibu.edu.tr

Phone: +903742541238

Fax: +90 3742534642 


\section{Introduction}

Natural products have been the source for the treatment of diseases since the dawn of human civilization, and through scientific and observational efforts from traditional medicine, modern medicine has slowly developed over the years. Besides the obvious use of raw plant preparations or plant extracts, plant-based natural product research has become a common tool in the production of drugs (MUKHERJEE \& al [1]). Scientific validations can be developed with bioassays on natural products originating from the traditional usages of medicinal plants.

A. millefolium has ethnobotanical records for the treatment of diarrhea, common cold, migraine, stomachache, headache, toothache, cough, hemorrhoids, uroclepsia, lung cancer, rheumatism, backache, nephritis, cardiopathy, migraine, dizziness, gynecological diseases, epistaxis and eye strain in traditional medicine. It possess vasodilator, antiseptic, wound cleaner, antiemetic, menstrual regulator, weight allowance, antitussive, diuretic, carminative, stomachic, urinary antiseptic, tonic, astringent, vulnerary, hemostatic, anticancer and analgesic properties (KÜLTÜR [2]; ALTUNDAG and OZTURK [3]; POLAT and SATIL [4]; GULER \& al [5]).

$P$. vulgaris has been used in the treatment of cystitis, female disorders, wounds, hemorrhoids, senses disorders, respiratory and gastrointestinal system ailments, blood system disorders, bleeding, anthrax, sore throat, headache, heart diseases, difficult breathing, gastric ulcer and weakness of eyesight due to overage in traditional medicine (ALTUNDAG and OZTURK [3]; GUARINO \& al [6]; KOYUNCU \& al [7]; ŠARIĆ-KUNDALIĆ \& al [8]). It has also used as a refreshing drink, and substitute of tobacco (KUJAWSKA \& al [9]). P. vulgaris has folkloric usage as expectorant, antiseptic, cicatrisant, intestinal antispasmodic, hepatoprotective, choleretic, antiulcer, antidiarrheal, antipyretic, laxative, tonic, diuretic and animal fodder (ALTUNDAG and OZTURK [3]; KOYUNCU \& al [7]; ŠARIĆ-KUNDALIĆ \& al [8]; REDZIC [10]; MUMCU and KORKMAZ [11]).

In traditional medicine, $P$. laciniata has been used for making infusions for the cough treatment, gall and skin diseases. It is used externally for cleaning open sores and wounds (REDZIC [12]). It is a wound healer (KOYUNCU $\&$ al [7]) and has been used in the diseases of the respiratory and gastrointestinal systems (GUARINO \& al [6]).

According to ethnobotanical records, L. salicaria has been used as a treatment in dysentery, diarrhea, intestinal inflammation, hematuria, leucorrhea, epistaxis, dysmenorrhea, lupus, eczema, impetigo, skin diseases, anemia, female urogenital inflammation, hemorrhoids, internal bleeding, stomach disorders, high blood pressure, gastrointestinal tract ailments, blood circulation disorders, dysentery, uterine hemorrhages, colitis and stomatitis. It has astringent, antihemorrhagic, tonic, vulnerary, cleansing and intestinal disinfectant activities (ŠARIĆKUNDALIĆ \& al [8]; REDZIC [10]; MUMCU and KORKMAZ [11]; TITA \& al [13]; DI NOVELLA \& al [14]; PIWOWARSKI \& al [15]).
E. hirsutum has been recorded in the treatment of gastritis, stomach disease, ulceration, inflammations, prostate tumors, rectal bleeding, constipation, menstrual and gastrointestinal disorders, weakness, nervous debility, stomachache, joint pains, skin allergies, acne, prostatitis, prostate adenoma, hepatitis, ulcer, enteritis, cirrhosis and urinary tract disorders in ethnobotanical studies and it has been used as depurative, cholagogue, astringent, antiinflammatory, haemostatic, antimicrobial, cytostatic, regenerative, hypertensive and animal fodder in folk medicine (TITA \& al [13]; AL-QURA'N [16]; ARNOLD \& al [17]; KORKMAZ \& al [18] ).

E. angustifolium has been used as a remedy in prostate diseases, benign prostate hyperplasia, prostatitis, prostate cancer, urinary disorders, stomachache, intestinal discomfort, enteritis, hepatitis, ulcer, cirrhosis, inflammation of mouth, blister, constipation, cuts, abdominal pain, burns, eye conditions due to asthma and allergies, female diseases, cardiovascular diseases, and mouth, hepatic, stomach, intestinal and renal complaints in traditional medicine. It has depurative, cholagogue, astringent, antidiarrheal, carminative, anti-inflammatory, haemostatic, antimicrobial, cytostatic, regenerative, laxative and blood cleanser properties, and been used as an antiseptic to treat infected wounds (TITA \& al [13];) MENALE \& al [19]; BALLABH and CHAURASIA [20]; CANSARAN \& KAYA [21]; BARTFAY \& al [22]; KORKMAZ [23]; AKAN and BAKIR [24]; KORKMAZ \& al [25]; SETZER [26]).

Pedicularis spp. have been used in the treatment of cold, cough, fever, sterility, rheumatism, general debility, collapse, poor appetite, chronic hepatitis, pancreatic disease, digestive, reproductive and urinary problems in traditional medicine (YATOO \& al [27]). Local people consume nectar of $P$. comosa by sucking their flowers in Iğdır, Turkey (ALTUNDAĞ ÇAKIR [28].

A. eupatoria has been used as a treatment in goiter, hernia, sore throat, laryngitis, pharyngitis, diarrhea, enteritis, gastritis, gut, anorexia, gall-bladder ailments, liver diseases, jaundice, fatty liver, stomach ulcers, digestive disorders, respiratory diseases, cardiovascular system disorders, gastrointestinal disorders, renal and biliary lithiasis, chronic cholecystitis rheumatism, headache, dermatitis, skin diseases, hemorrhoids and snake bites. It has constipant, diuretic, astringent, hypotensive, cholagogue, sedative, anti-inflammatory, antiaphonic, antilithiase, cicatrisant, blood purifier, vulnerary, depurative, gastric analgesic, hepatic, antiulcerose, antidiarrheal, anthelmintic and tonic properties. A. eupatoria has also records as renal, bladder, bronchial, intestinal and hepatic anti-inflammatory in folkloric medicine (KÜLTÜR [2]; ALTUNDAG and OZTURK [3]; GUARINO \& al [6]; TITA \& al [13]; KORKMAZ [25]; SETZER [26]; YATOO \& al [27]; ALTUNDAG ÇAKIR [28]; CAKILCIOGLU and TURKOGLU [29]; CAVERO and CALVO [30]; OZTURK [31]).

$V$. officinalis has healing property in cough, asthma, cold-fever, constipation, milk secretion, muscular pains, contusions and bruises, herpes zoster, ascaris, snake bite, eczemas, furuncle, boil, sore throat, sinusitis, jaundice, hepatitis, enteritis, convulsion, colitis, migraine, depression, insomnia, nervous headache, urinary problems, menstrual 
cramps, and stomach, intestine, liver, spleen, gall bladder and kidney disorders. It has been recorded as antiarthrosic, antirheumatic, antipneumonic, antiechimotic, antihaemastenic, antianemic, astringent, tonic, diaphoretic, antispasmodic, emmenagogue for late menstruation, cardiotonic, febrifuge, stimulant, restorative, stomachache, tranquillizer, hepatoprotective, liver stimulant, choleretic, antiulcer, diuretic against dropsy, antidiarrheal, aphrodisiac, analgesic, anticonvulsant, learning and memory enhancer, antidepressant and sedative in traditional medicine (GUARINO \& al [6]; REDZIC [10]; MUMCU and KORKMAZ [11]; CAKILCIOGLU and TURKOGLU [29]; BONET \& al [32]).

The objective of this study was to assess antibacterial and antioxidant potentials of nine plant species correlating with their ethnomedicinal knowledge and to determine their phenolic constituents by HPLC-DAD analysis.

\section{Materials and Methods}

\section{Plant material and extraction}

Nine different plant species were collected in Bolu, Turkey and identification was performed using Flora of Turkey and the East Aegean Islands" (DAVIS [33]). Table 1 included family, botanical and common names, and collection number of tested species, besides extraction solvent types and yield for each extract. Above ground parts were used for each extraction of plants. Plant samples were powdered after drying for preparation of extracts. Twenty grams of plant materials were extracted with water or methanol $(\mathrm{MeOH})$ at $40^{\circ} \mathrm{C}$ by using water bath for $24 \mathrm{~h}$ and then filtered. Methanolic extract was concentrated using rotary evaporator and dissolved in water. Aqueous and methanol extracts were finally lyophilized and powdered crude extract was obtained.

Table 1. Botanical and common names, collection numbers, extraction types and yield (\%) of plants.

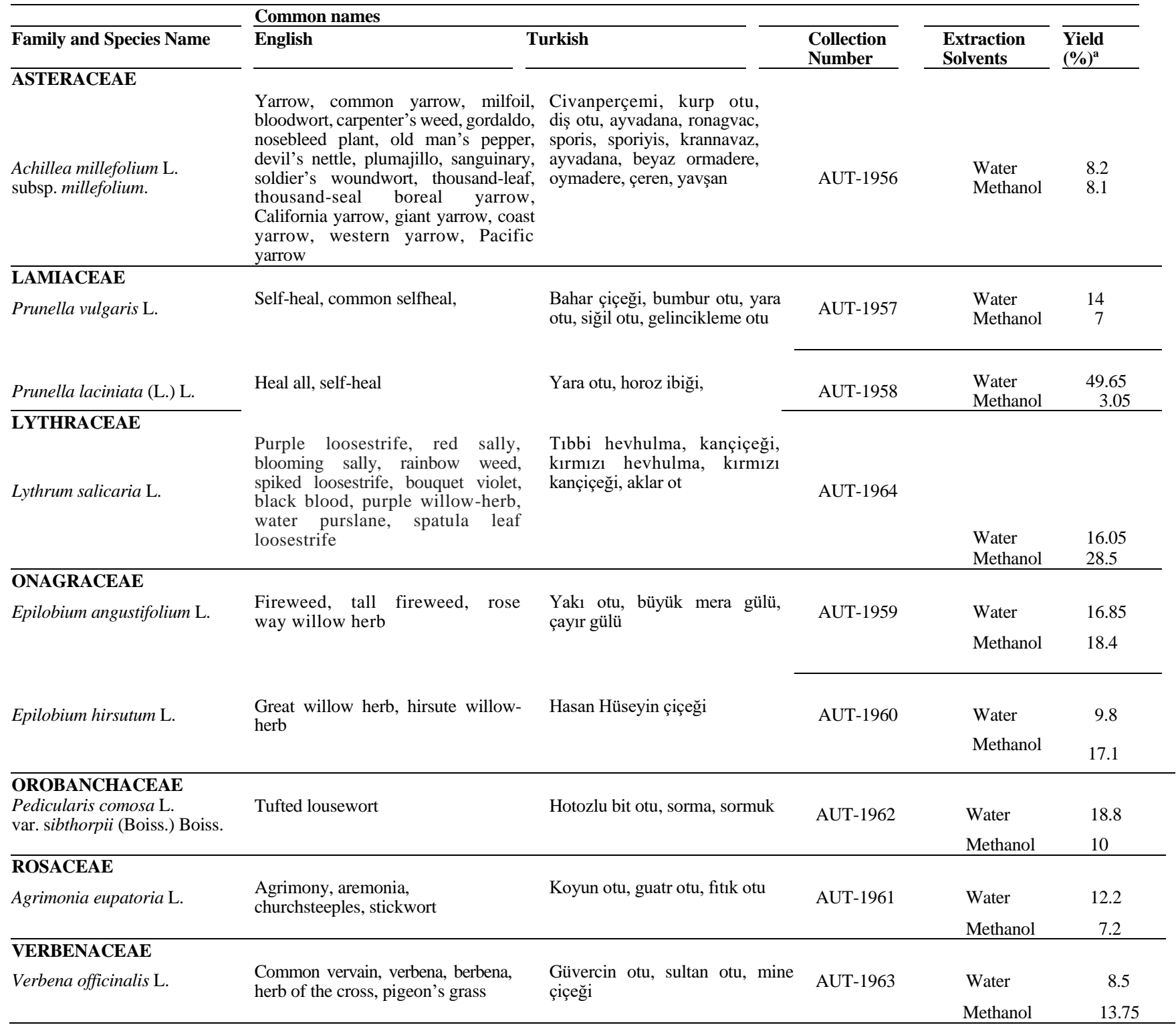

${ }^{\mathrm{a}}$ Yield $(\%)=$ Weight of extract $(\mathrm{g}) / 20 \mathrm{~g}$ of plant sample $\mathrm{X} 100$ 


\section{Antibacterial bioassay}

Three gram-positive bacteria [Streptococcus pyogenes (ATCC $\left.{ }^{\circledR} 19615\right)$, Staphylococcus aureus $\left(\right.$ ATCC $^{\circledR} 25923$ ) and Staphylococcus epidermidis $\left.\left(\mathrm{ATCC}^{\circledR} 12228\right)\right]$ and seven gram-negative bacteria [Escherichia coli $\left(\mathrm{ATCC}^{\circledR}\right.$ 25922), Pseudomonas aeruginosa $\left(\mathrm{ATCC}^{\circledR} 27853\right)$, Salmonella typhimurium $\left(\mathrm{ATCC}^{\circledR} 14028\right)$, Serratia marcescens (ATCC $^{\circledR}$ 8100), Proteus vulgaris (ATCC $^{\circledR}$ 13315), Enterobacter cloacae $\left(\mathrm{ATCC}^{\circledR} 23355\right)$ and Klebsiella pneumoniae $\left(\mathrm{ATCC}^{\circledR} 13883\right)$ ] were used for disc diffusion assay according to method described by YILDIRIM \& al. [34]. Firstly, turbidity of each broth culture of bacteria was adjusted with saline ( $0.5 \mathrm{McF}$ arland) and then inoculated into Mueller Hinton agar plates using cotton swabs. All extracts were dissolved in dimethyl sulfoxide (DMSO, Sigma $\left.{ }^{\circledR}\right)(100 \mathrm{mg} / \mathrm{mL})$ and then sterile filter paper discs (Glass microfibre filters, Whatman ${ }^{\circledR}$; $6 \mathrm{~mm}$ diameter $)$ including filter-sterilized extracts $(0.22 \mu \mathrm{m}$ filter-Acrodisc ${ }^{\circledR}$ ) were placed into inoculated plates. There were two plates containing five replicates for each extract tested for each bacterium. Erythromycin, ampicillin, carbenicillin, tetracycline and chloramphenicol (Bioanalyse ${ }^{\circledR}$ ) were used as positive controls. Negative control was DMSO. Incubation period was 24 hours at $37^{\circ} \mathrm{C}$ and then each disc was measured to evaluate the diameter of inhibition zones. All experiments were repeated three times.

\section{Free radical scavenging activity}

Free radical scavenging activity of the methanol extracts of plant species was assesed spectrophotometrically by using 2,2-diphenyl-1-picrylhydrazil (DPPH•, Sigma $\left.{ }^{\circledR}\right)$ according to method described by YILDIRIM \& al. [34]. DPPH was mixed with the extracts at different concentrations $(12.5,25,50,100$ and $200 \mu \mathrm{g} / \mathrm{mL})$, vortexed and then kept in the dark for $30 \mathrm{~min}$. Decline in the absorbance was measured at $517 \mathrm{~nm}$ (Hitachi U-1900, UV-VIS Spectrophotometer 200V) against blank samples. All analyses were made in triplicate.

\section{Determination of total phenolic content}

Folin-Ciocalteu phenolic reagent $\left(\mathrm{Sigma}^{\circledR}\right.$ ) was used to determine total phenolic contents of methanolic extracts according to method described by YILDIRIM \& al [34]. Calibration curve of gallic acid $\left(\mathrm{Sigma}^{\circledR}\right)(0,50,100,150$, 200, 250 and $500 \mathrm{mg} / \mathrm{L}$ ) was prepared as standard. Plant extracts, each concentration of gallic acid and blank were mixed with Folin-Ciocalteu reagent and were neutralized with aqueous sodium carbonate $\left(\mathrm{Na}_{2} \mathrm{CO}_{3}\right)$. The mixture was incubated at room temperature for 2 hours. The absorbance of each solution was measured at $765 \mathrm{~nm}$ against the blank using the spectrophotometer. Total phenolic compounds in plant extracts were calculated according to the calibration curve of gallic acid. Total phenolic was presented as $\mathrm{mg} / \mathrm{g}$ gallic acid equivalent (GAE) of dry extract. Three replicates were performed.

\section{Determination of total flavonoid}

Aluminum chloride $\left(\mathrm{AlCl}_{3}\right)$ colorimetric assay was used to determine the amount of total flavonoids in the methanol extracts according to method described by YILDIRIM \& al [34]. Calibration curve of catechol $\left(\right.$ Sigma $\left.^{\circledR}\right)(20,40,60,80$ and $100 \mathrm{mg} / \mathrm{mL})$ was prepared as standard. Extract solution or standard was mixed distilled water and sodium nitrite $\left(\mathrm{NaNO}_{2}\right)$ and after $5 \mathrm{~min}, 10 \%$ $\mathrm{AlCl}_{3}$ was added to the test tubes. Thereafter, sodium hydroxide $(\mathrm{NaOH})$ and distilled water was added to the mixture. The absorbance of the mixture was determined at $510 \mathrm{~nm}$. Total flavonoid compounds in plant extracts were calculated according to the calibration curve of catechol. Total flavonoid was presented as $\mathrm{mg} / \mathrm{g}$ catechol equivalent (CAE) of dry extract. Three replicates were performed.

\section{High-Performance Liquid Chromatography (HPLC) analysis}

Ten phenolic standards (gallic acid monohydrate, caffeic acid, rutin hydrate, luteolin-7-O- $\beta$-D glucoside, kaempferol, rosmarinic acid, myricetin, quercetin, coumarin and apigenin) $\left(\right.$ Sigma $\left.^{\circledR}\right)$ were used as reference. All standards were prepared at $1 \mathrm{mg} / \mathrm{mL}$ in acetonitrile $(\mathrm{ACN})$ and mixed together to get different concentrations $(1,5,10,20,40,60,80,100$ and $200 \mathrm{mg} / \mathrm{L})$ for plotting the standard curve. The chromatogram of the used standards was presented in Figure 1. All methanolic extracts and standards were filtered through a $0.2-\mu \mathrm{m}$ GHP Acrodisc $(25 \mathrm{~mm})$ (Pall Corporation) into $2 \mathrm{~mL}$ HPLC vials. HPLC system (VWR-Hitachi LaChrom Elite ${ }^{\circledR}$ ) equipped with a Hitachi L-2455 diode array detector (DAD), Hitachi L-2130 Pump, Hitachi L-2200 autosampler was used for analysis. Chromatographic separation was achieved using Hitachi column oven L-2300 and Venusil XBP C18 column (Bonna-Agela Technologies, particle size $5 \mu \mathrm{m}, 4.6 \times 250 \mathrm{~mm}$ ). Flow rate was $1 \mathrm{~mL} / \mathrm{min}$ with $25^{\circ} \mathrm{C}$ oven and injection volume was $20 \mu \mathrm{L}$. All solvents were HPLC grade $\left(\right.$ Merck $^{\circledR}$ ) and the mobile phase was composed of solvent (A) acetonitrile (ACN) and solvent (B) $0.1 \%$ acetic acid. The gradient program was started with $10 \%$ of $\mathrm{A}$ and $90 \%$ of B at 0 min and changed to obtain $20 \%, 40 \%, 60 \%, 80 \%$, $10 \% \mathrm{~A}$ at 5, 10, 15, 20 and $20.1 \mathrm{~min}$, respectively. Mobile phases and ultrapure water (SG Labostar) were filtered through a $0.45 \mu \mathrm{m}$ hydrophilic polypropylene membrane filter $(47 \mathrm{~mm})$ (Pall Corporation) prior to HPLC injection. Spectra data were recorded from to 200 to $400 \mathrm{~nm}$ during the entire run. The chromatograms were obtained at $280 \mathrm{~nm}$ 


\section{Data analysis}

All data were analyzed by analysis of variance (ANOVA) and mean values were compared with Duncan's Multiple Range Tests using SPSS vers. 15 (SPSS Inc., Chicago, IL, USA).

\section{Results and Discussion}

Nine plant species used in traditional medicine (Table 1) were evaluated for their antibacterial (Table 2) and antioxidant (Table 3 ) potentials, and phenolic profiles (Table 4 and 5).

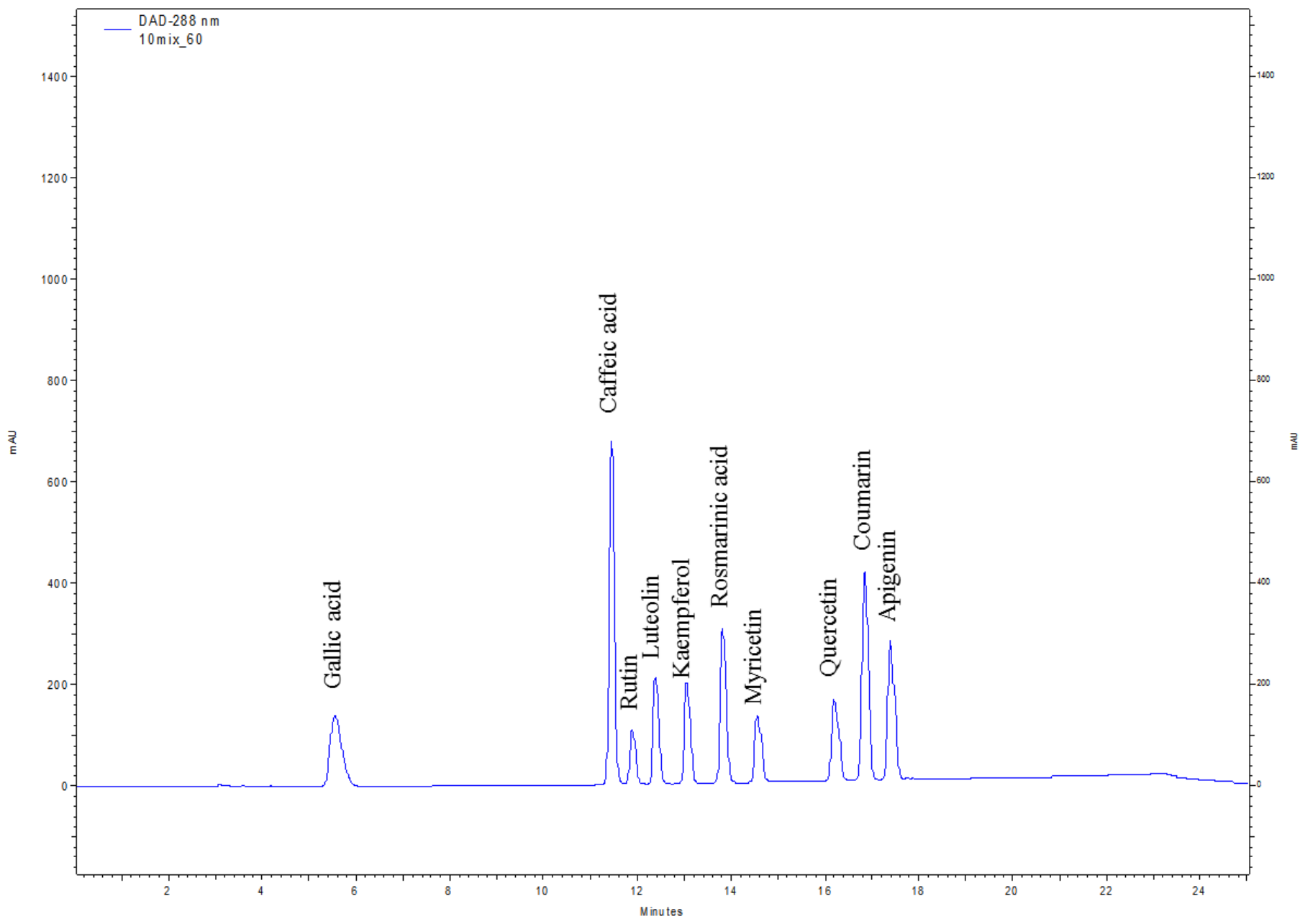

Figure 1. Chromatogram of the standards.

\section{Antibacterial potential}

Inhibition zone diameters for aqueous and methanol extractions of nine plant species against ten different bacterial strains were reported in Table 2. Plant extracts showed strong antibacterial activity against gram positive bacteria (S. aureus, S. epidermidis and $S$. pyogenes) in general. It may come from differences in cell wall structure in that gram-positive bacteria have single layer cell wall. On the other hand, gram-negative bacteria have multilayered cell wall structure and it may provide strength against plant extracts. Tested bacteria were generally susceptible to positive controls (tested reference antibiotic discs). Final concentrations of all extracts were adjusted with DMSO and it was used as negative control. There was no inhibition with DMSO (Table 2).

Best antibacterial activity was observed with $E$. hirsutum against all tested gram positive bacteria. E. angustifolium also showed strong inhibition against these bacteria. Folkloric usage record of E. hirsutum for the treatment of acne and $E$. angustifolium for the cuts and wound may be explained with the strong inhibitory activity of these plants against gram positive bacteria especially $S$. epidermidis. Moreover, both plants exhibited the best inhibition against $P$. vulgaris, a gram negative bacterium. 
Table 2. Antibacterial potential of tested plant extracts and controls. Data were presented as a mean diameter of inhibition zones \pm standard error (SE). Means with the same letter within columns are not significantly different at $P>0.05$. W: Water, M: Methanol, DMSO: Dimethyl sulfoxide.

\begin{tabular}{|c|c|c|c|c|c|c|c|c|c|c|c|}
\hline \multirow{2}{*}{ Treatments } & & \multicolumn{10}{|c|}{ Mean Diameter of Inhibitory Zones $(\mathrm{mm} \pm \mathrm{SE})$} \\
\hline & & $\begin{array}{c}\text { S. } \\
\text { aureus }\end{array}$ & $\begin{array}{c}\text { S. } \\
\text { epidermidis }\end{array}$ & $\begin{array}{c}S . \\
\text { pyogenes }\end{array}$ & $\begin{array}{c}S . \\
\text { marcescens }\end{array}$ & $\begin{array}{c}S . \\
\text { typhimurium }\end{array}$ & $\begin{array}{c}P . \\
\text { aeruginosa }\end{array}$ & $\begin{array}{c}P . \\
\text { vulgaris }\end{array}$ & $\begin{array}{c}\text { K. } \\
\text { pneumonia }\end{array}$ & $\begin{array}{c}E . \\
\text { cloacae }\end{array}$ & $\begin{array}{c}E . \\
\text { coli }\end{array}$ \\
\hline \multirow{2}{*}{ A. millefolium } & $\mathrm{W}$ & - & - & - & - & - & - & - & - & - & - \\
\hline & M & $9.9 \pm 0.4^{\mathrm{i}}$ & - & - & - & - & - & - & - & - & - \\
\hline \multirow{2}{*}{ P. vulgaris } & $\mathrm{W}$ & $9.4 \pm 0.2^{\mathrm{ij}}$ & $10.4 \pm 0.2^{\mathrm{h}}$ & $8.2 \pm 1.8^{j}$ & - & - & - & - & - & - & - \\
\hline & $\mathrm{M}$ & - & $10.2 \pm 0.2^{\mathrm{h}}$ & - & - & - & - & - & - & - & - \\
\hline \multirow{2}{*}{ P. laciniata } & $\mathrm{W}$ & - & - & - & - & - & - & - & - & - & - \\
\hline & M & - & - & - & - & - & - & - & - & - & - \\
\hline \multirow{2}{*}{ L. salicaria } & $\bar{W}$ & $15.9 \pm 0.5^{\mathrm{fg}}$ & $17.7 \pm 0.8^{\mathrm{g}}$ & $14.4 \pm 0.8^{\mathrm{h}}$ & - & - & - & $11.8 \pm 1.0^{\mathrm{gh}}$ & $9.3 \pm 0.3^{\mathrm{e}}$ & - & - \\
\hline & M & $18.7 \pm 0.4^{\mathrm{e}}$ & $20.4 \pm 0.4^{\mathrm{de}}$ & $16.8 \pm 1.4^{\mathrm{g}}$ & - & - & $11.2 \pm 0.5^{\mathrm{c}}$ & $14.0 \pm 0.7^{\mathrm{fg}}$ & $10.4 \pm 0.5^{\mathrm{d}}$ & - & - \\
\hline \multirow{2}{*}{ E. angustifolium } & $\overline{\mathrm{W}}$ & $13.3 \pm 1.3^{\mathrm{h}}$ & $18.2 \pm 1.3^{\mathrm{fg}}$ & $14.0 \pm 0.9^{h}$ & - & - & - & $15.2 \pm 1.2^{\mathrm{ef}}$ & - & - & - \\
\hline & $\mathrm{M}$ & $15.0 \pm 0.4^{\mathrm{g}}$ & $18.4 \pm 0.3^{\mathrm{fg}}$ & $16.4 \pm 0.9^{\mathrm{g}}$ & - & - & - & $17.3 \pm 0.5^{\mathrm{de}}$ & - & - & - \\
\hline \multirow{2}{*}{ E. hirsutum } & $\overline{\mathrm{W}}$ & $16.7 \pm 0.7^{\mathrm{f}}$ & $19.3 \pm 0.9^{\mathrm{ef}}$ & $16.4 \pm 1.0^{\mathrm{g}}$ & - & - & - & $12.5 \pm 2.7^{\mathrm{gh}}$ & - & - & - \\
\hline & $\mathrm{M}$ & $18.4 \pm 0.5^{\mathrm{e}}$ & $20.7 \pm 0.4^{\mathrm{d}}$ & $20.8 \pm 0.5^{\mathrm{f}}$ & - & - & $9.3 \pm 0.2^{\mathrm{d}}$ & $17.8 \pm 0.9^{\mathrm{d}}$ & - & - & - \\
\hline \multirow{2}{*}{ A. eupatoria } & $\overline{\mathrm{W}}$ & $8.4 \pm 0.2^{j}$ & - & $9.6 \pm 0.2^{\mathrm{ij}}$ & - & - & - & - & - & - & - \\
\hline & $\mathrm{M}$ & $15.4 \pm 0.2^{\mathrm{g}}$ & $17.6 \pm 0.6^{\mathrm{g}}$ & $20.0 \pm 0.0^{\mathrm{f}}$ & - & - & - & $11.4 \pm 0.2^{\mathrm{h}}$ & - & - & - \\
\hline \multirow{2}{*}{ P. comosa } & $\mathrm{W}$ & - & - & - & - & - & - & - & - & - & - \\
\hline & $\mathrm{M}$ & - & $9.4 \pm 0.2^{h}$ & $9.2 \pm 0.2^{\mathrm{ij}}$ & - & - & - & - & - & - & - \\
\hline \multirow{2}{*}{ V. officinalis } & $\bar{W}$ & - & - & - & - & - & - & - & - & - & - \\
\hline & M & - & - & $10.7 \pm 0.3^{\mathrm{i}}$ & - & - & - & - & - & - & - \\
\hline Ampicillin & & $34.5 \pm 0.3^{\mathrm{b}}$ & $29.0 \pm 1.2^{\mathrm{c}}$ & $50.5 \pm 1.4^{\mathrm{b}}$ & - & $27.0 \pm 0.0^{\mathrm{b}}$ & - & $23.0 \pm 0.0^{\mathrm{c}}$ & $7.5 \pm 0.3^{f}$ & $26.5 \pm 0.3^{\mathrm{c}}$ & $20.0 \pm 0.0^{\mathrm{d}}$ \\
\hline Carbenicillin & & $36.0 \pm 0.0^{\mathrm{a}}$ & $33.0 \pm 0.0^{\mathrm{b}}$ & $54.0 \pm 1.7^{\mathrm{a}}$ & $22.5 \pm 1.4^{\mathrm{b}}$ & $27.0 \pm 0.0^{\mathrm{b}}$ & $22.0 \pm 0.0^{\mathrm{a}}$ & $29.0 \pm 0.0^{\mathrm{a}}$ & - & $32.0 \pm 0.6^{\mathrm{a}}$ & $28.0 \pm 0.0^{\mathrm{a}}$ \\
\hline Chloramphenicol & & $24.5 \pm 0.9^{\mathrm{d}}$ & $32.3 \pm 0.8^{\mathrm{b}}$ & $36.0 \pm 0.6^{\mathrm{e}}$ & $24.0 \pm 0.6^{\mathrm{a}}$ & $28.5 \pm 0.9^{\mathrm{a}}$ & $8.5 \pm 0.3^{\mathrm{e}}$ & $26.0 \pm 0.0^{\mathrm{b}}$ & $23.0 \pm 0.0^{\mathrm{b}}$ & $26.5 \pm 0.9^{c}$ & $27.0 \pm 0.0^{\mathrm{b}}$ \\
\hline Erythromycin & & $28.5 \pm 0.9^{\mathrm{c}}$ & $37.0 \pm 0.0^{\mathrm{a}}$ & $44.5 \pm 0.3^{\mathrm{c}}$ & $7.0 \pm 0.0^{\mathrm{d}}$ & $9.0 \pm 0.6^{\mathrm{d}}$ & $8.0 \pm 0.0^{\mathrm{f}}$ & $11.0 \pm 0.0^{\mathrm{h}}$ & $11.5 \pm 0.9^{\mathrm{c}}$ & - & $11.0 \pm 0.0^{\mathrm{e}}$ \\
\hline Tetracycline & & $28.5 \pm 0.9^{\mathrm{c}}$ & - & $41.5 \pm 0.9^{\mathrm{d}}$ & $18.0 \pm 1.2^{\mathrm{c}}$ & $21.0 \pm 0.6^{\mathrm{c}}$ & $12.5 \pm 0.3^{\mathrm{b}}$ & $28.5 \pm 0.3^{\mathrm{a}}$ & $24.5 \pm 0.3^{\mathrm{a}}$ & $28.5 \pm 0.9^{b}$ & $26.5 \pm 0.3^{\mathrm{c}}$ \\
\hline DMSO & & - & - & - & - & - & - & - & - & - & - \\
\hline
\end{tabular}

Strong antibacterial activity of these plants against P. vulgaris may explain why Epilobium species are used in traditional medicine to treat urinary tract disorders. E. angustifolium was recorded as antibacterial against $S$. aureus, $P$. aeruginosa and E. coli (BARTFAY \& al [22]; RAUHA \& al [35]). Similar to previous studies, both E. angustifolium and E. hirsutum exhibited strong antibacterial activity against $S$. aureus. But, only E. hirsutum showed potent inhibition against $P$. aeruginosa and no inhibition was observed against $E$. coli with both Epilobium species in our study (Table 2). KUNDUHOGLU \& al [36] showed that ethanol extract of E. hirsutum flowers had antibacterial activity against $S$. aureus, $S$. epidermidis, $E$. coli and $S$. typhimurium. But, stem of this plant showed an inhibitory effect against only $S$. aureus and $S$. epidermidis but not $E$. coli and $S$. typhimurium. Similar to this study, aerial part of E. hirsutum including flowers and stem together demonstrated antibacterial effect against $S$. aureus and $S$. epidermidis but no activity was observed against $E$. coli and $S$. typhimurium in our study. PIRVU \& al [37] also reported strong antibacterial activity of E. hirsutum against E. coli and $S$. aureus (17 $\mathrm{mm}$ for both of them).
The broadest spectrum of antibacterial activity was observed with $L$. salicaria. In addition to the inhibition against gram positive bacteria, 3 gram negative bacteria ( $P$. aeruginosa, $P$. vulgaris and $K$. pneumonia) were susceptible to methanol extract of $L$. salicaria (Table 2). $L$. salicaria has been used as curative purpose in the skin diseases and inflammations, and as intestinal disinfectant. Broad spectrum antibacterial activity of this plant supports these traditional usages. Vulnerary activity of $L$. salicaria in folkloric usage may be due to its strong antibacterial activity against $S$. aureus, $S$. pyogenes, $S$. epidermidis, $P$. vulgaris and $P$. aeruginosa. Although RAUHA \& al [35] reported strong antibacterial activity of $L$. salicaria against $E$. coli and slight activity against $S$. aureus, strong antibacterial activity against $S$. aureus $(18.7 \mathrm{~mm})$ and no activity against $E$. coli were observed in our study (Table 2). PIRVU \& al [37] also showed weak antibacterial activity of $L$. salicaria against $E$. coli $(8 \mathrm{~mm})$ and moderate activity against $S$. aureus $(12 \mathrm{~mm})$. In consistent with our study, BECKER \& al [38] reported strong antibacterial activity of $L$. salicaria against $S$. aureus and no activity against $E$. coli.

Methanolic extract of $P$. vulgaris was effective against all tested gram positive bacteria and exhibited medium 
strength inhibition against these bacteria. However, antibacterial activity was not observed with $P$. laciniata against any bacteria. According to ethnobotanical records, $P$. vulgaris has a remedy in respiratory and gastrointestinal system ailments, sore throat and wounds. Moderate antibacterial activity of $P$. vulgaris against gram positive bacteria may explain and justify these traditional usages. $P$. laciniata has been recorded for the treatment of cough, skin diseases and wounds in traditional medicine. Antibacterial activity of $P$. laciniata was not observed against 10 bacteria in our study and antibacterial results did not support these traditional usages for $P$. laciniata. It was reported in one study that $P$. vulgaris extract inhibited $P$. aeruginosa, E. coli, $P$. vulgaris, $S$. aureus and no activity was observed against K. pneumoniae (KIRBAG \& al [39]). But, only $S$. aureus, S. epidermidis and $S$. pyogenes were sensitive to $P$. vulgaris extract and no inhibition was observed with other bacteria in our study ( $P$. aeruginosa, E. coli, P. vulgaris and K. pneumoniae) (Table 2).

Only $S$. aureus was sensitive to A. millefolium in our study. A. millefolium has been used as an antiseptic, wound cleaner and a remedy in common cold and cough in folk medicine. Moderate inhibition of $S$. aureus may explain these uses. One previous study showed inhibition against E. coli in addition to S. aureus (FAIKU \& al [40]). In consistent to our result, BOBIS \& al [41] reported that A. millefolium exhibited inhibition against $S$. aureus but no inhibition was observed against $S$. typhimurium, E. coli and $P$. aeruginosa. On the other hand AFSHARI \& al [42] indicated the sensitivity of E. coli, S. epidermidis and $S$. typhimurium against $A$. millefolium extract. CANDAN $\&$ al. [43] determined that water soluble portion of methanolic extract of $A$. millefolium did not show antibacterial activity against $S$. aureus, E. coli, $P$. aeruginosa and K. pneumoniae. On the other hand, SHAHBAZI and ZADEH [44] exhibited antibacterial activity of A. millefolium alcoholic extract against wound pathogen microorganism such as $S$. aureus, K. pneumoniae, P. aeruginosa and E. coli.

Methanolic extract of $A$. eupatoria was very potent on all tested gram positive bacteria. Furthermore, gram negative bacteria $P$. vulgaris was sensitive to this extract in our study (Table 2). According to ethnobotanical records, A. eupatoria has therapeutic potential in sore throat, laryngitis, pharyngitis, respiratory diseases, dermatitis, skin diseases and wounds. Very potent inhibitory activity against $S$. aureus, S. epidermidis and S. pyogenes, and moderate activity against $P$. vulgaris may justify above traditional usages. One study reported that ethanol extract of A. eupatoria showed inhibition against E. coli, $P$. aeruginosa, K. pneumoniae and S. aureus (MURUZOVIĆ \& al [45]).

Only $S$. pyogenes was susceptible to methanolic extract of $V$. officinalis (Table 2). CAVERO and CALVO [30] highlighted the value of $V$. officinalis in the treatment of respiratory problem after reviewing many ethnobotanical, phytochemical and pharmacological studies. Moderate antibacterial activity of $V$. officinalis against $S$. pyogenes may prove the traditional usage of this plant in the treatment of cough, sore throat, sinusitis and boils. SISAY $\&$ al [46] reported that $80 \%$ methanol extracts of the leaves of $V$. officinalis displayed antibacterial activity against $S$. aureus and E. coli, and no activity against $P$. aeruginosa. AHMED \& al [47] investigated ethanolic extract of leaves and stem of $V$. officinalis. They observed that $S$. aureus, $S$. epidermidis, $K$. pneumoniae, $P$. aeruginosa and $E$. coli were susceptible to this ethanolic extract.

\section{Antioxidant capacity}

Among the tested plant species, $P$. laciniata, $E$. angustifolium and $L$. salicaria showed the highest antioxidant capacities. A. eupatoria, E. hirsutum and $P$. comosa also had very potent radical scavenging capacity $(<12.5 \mu \mathrm{g} / \mathrm{mL})$ (Table 3$)$.

Table 3. Free radical scavenging activity of tested plant extracts. IC 50 : The half maximal inhibitory concentration.

\begin{tabular}{|c|c|c|c|c|c|c|}
\hline \multirow[b]{2}{*}{ Treatments } & \multirow[b]{2}{*}{$\mathrm{IC}_{50}(\boldsymbol{\mu g} / \mathrm{mL})$} & \multicolumn{5}{|c|}{$\begin{array}{c}\text { \% DPPH Inhibition } \\
\text { Concentrations }\end{array}$} \\
\hline & & $12.5 \mu \mathrm{g} / \mathrm{mL}$ & $25 \mu \mathrm{g} / \mathrm{mL}$ & $50 \mu \mathrm{g} / \mathrm{mL}$ & $100 \mu \mathrm{g} / \mathrm{mL}$ & $200 \mu \mathrm{g} / \mathrm{mL}$ \\
\hline Ascorbic acid & $<12.5$ & 90.1 & 91.2 & 96.0 & 96.5 & 99.7 \\
\hline A. millefolium & $26.9 \pm 3.3$ & 20.8 & 45.1 & 78.9 & 92.5 & 92.2 \\
\hline P. vulgaris & $18.9 \pm 2.9$ & 32.8 & 52.2 & 85.9 & 90.5 & 91.8 \\
\hline P. laciniata & $<12.5$ & 88.9 & 89.3 & 90.3 & 90.4 & 91.7 \\
\hline L. salicaria & $<12.5$ & 81.0 & 88.7 & 88.9 & 93.7 & 96.2 \\
\hline E. angustifolium & $<12.5$ & 81.0 & 92.3 & 95.4 & 98.2 & 98.2 \\
\hline E. hirsutum & $<12.5$ & 71.6 & 81.2 & 88.7 & 88.4 & 91.1 \\
\hline A. eupatoria & $<12.5$ & 73.3 & 79.5 & 80.7 & 83.9 & 83.2 \\
\hline P. comosa & $<12.5$ & 68.6 & 87.5 & 93.5 & 95.9 & 96.8 \\
\hline V. officinalis & $33.1 \pm 3.2$ & 19.4 & 23.1 & 79.9 & 90.8 & 90.5 \\
\hline
\end{tabular}

In regard to total phenol-flavonoid content of the tested species, E. hirsutum had the highest total phenolic content $[331.58 \mathrm{mg}$ gallic acid equivalent (GAE)/g dry extract] and L. salicaria had the highest total flavonoid content [346.67 mg catechol equivalent (CAE)/g dry extract] (Table 4). 
Table 4. Total phenolic and flavonoid content of tested plant extracts. Data were presented as a mean number \pm standard error (SE). GAE: Gallic acid equivalent, CE: Catechol equivalent.

\begin{tabular}{lcc}
\hline Treatments & $\begin{array}{c}\text { Total Phenolics in mg GAE/g } \\
\text { dry extract }\end{array}$ & $\begin{array}{c}\text { Total Flavonoids in mg CE/g } \\
\text { dry extract }\end{array}$ \\
\hline A. millefolium & $87.33 \pm 0.01$ & $464.38 \pm 0.01$ \\
P. vulgaris & $190.21 \pm 0.02$ & $266.00 \pm 0.001$ \\
P. laciniata & $222.64 \pm 0.05$ & $220.00 \pm 0.001$ \\
L. salicaria & $311.88 \pm 0.04$ & $346.67 \pm 0.001$ \\
E. angustifolium & $215.06 \pm 0.04$ & $178.86 \pm 0.001$ \\
E. hirsutum & $331.58 \pm 0.03$ & $259.43 \pm 0.001$ \\
A. eupatoria & $260.97 \pm 0.12$ & $264.76 \pm 0.001$ \\
P. comosa & $91.12 \pm 0.02$ & $115.62 \pm 0.001$ \\
V. officinalis & $102.03 \pm 0.02$ & $280.67 \pm 0.001$ \\
\hline
\end{tabular}

Oxidative stress is an imbalance between reactive oxygen species (ROS) production and their removal through defensive mechanisms that can give rise to chronic inflammation. Oxidative stress-triggered inflammation is the cause of many chronic diseases. Polyphenols, associated with antioxidant activity, are suggested to be useful as booster therapy for their possible anti-inflammatory impact. Phenolic compounds and flavonoids can interfere with ROS and thus stop the chain reaction before seriously affecting cell viability (HUSSAIN \& al [48]). Anti-inflammatory properties of E. angustifolium, E. hirsutum, L. salicaria and A. eupatoria in the treatment of various diseases have been recorded in traditional medicine. Strong free radical scavenging activities and higher total phenol-flavonoid content of these species support this property.

Similar to our results, E. angustifolium showed high radical scavenger activity in one previous study (TÓTH \& al [49]). DENG \& al [50] showed that ethanol extract of E. angustifolium had potent antioxidant activities in DPPH radical scavenging activity with $\mathrm{EC}_{50}$ of $25.53 \mu \mathrm{g} / \mathrm{mL}$ that is lower than our result $(<12.5 \mu \mathrm{g} / \mathrm{mL})$. PIRVU \& al [37] exhibited very strong scavenger potency of $L$. salicaria and $E$. hirsutum $\left(\mathrm{IC}_{50}=2.83\right.$ and $4.66 \mu \mathrm{g} / \mathrm{mL}$, respectively) that is higher than our result $(<12.5 \mu \mathrm{g} / \mathrm{mL})$. MANAYI $\&$ al [51], LOPEZ \& al [52] and TUNALIER \& al [53] reported strong antioxidant activity of $L$. salicaria as $\mathrm{IC}_{50}$ of $13.52 \mu \mathrm{g} / \mathrm{mL}, 4.84 \mu \mathrm{g} / \mathrm{mL}$, and $0.3 \mathrm{mg} / \mathrm{mL}$, respectively. Our results were in agreement with those reported by WOJDYŁO \& al. [54] in that E. angustifolium had high total phenolic content $(4.03 \mathrm{mg}$ of GAE/100 $\mathrm{g}$ of dry weight). Furthermore, DENG \& al. [50] reported higher phenolic and flavonoids compounds (16.81 g GAE/100 g extract and $4.95 \mathrm{~g}$ quercetin equivalent (QE)/100 g extract, respectively) in ethanol extract of $E$. angustifolium than our results (Table 4). MANAYI \& al [51] indicated high total phenol and flavonoid content of L. salicaria as $331 \mu \mathrm{g}$ GAE/mg and $5.8 \mu \mathrm{g}$ QE/mg, respectively. TUNALIER \& al [53] demonstrated high total phenol and flavonoid content of L. salicaria as $191.35 \mathrm{mg} \mathrm{GAE} / \mathrm{g}$ extract and $37.57 \mathrm{mg}$ rutin equivalents (RE)/g extract, respectively. Ethanol extract $(70 \%)$ of L. salicaria was recorded having total phenolic and flavonoid compounds as $17.5 \%$ tannin equivalent/g dried plant and $0.594 \% \mathrm{QE} / \mathrm{g}$ dried plant, respectively (HUMADI \& al [55]). On the other hand, methanolic extract of $L$. salicaria had total phenolic and flavonoid compounds as $31.1 \% \mathrm{GAE} / \mathrm{g}$ dry extract and $34.6 \% \mathrm{CAE} / \mathrm{g}$ dry extract, respectively in our study (Table 4).

The highest total flavonoid content and the lowest total phenolic content was obtained with A. millefolium having $464.38 \mathrm{mg} \mathrm{CAE} / \mathrm{g}$ dry extract and $87.33 \mathrm{mg} \mathrm{GAE} / \mathrm{g}$ dry extract, respectively (Table 4). On the other hand, BOBIS \& al [41] demonstrated that A. millefolium had total phenolic and flavonoid content as $134.65 \mathrm{mg}$ GAE/g and $42.6 \mathrm{mg}$ QE/g dry weight of plant, respectively. Total phenolic and flavonoid content of A. millefolium were recorded by AFSHARI \& al [42] as $48.10 \mathrm{mg}$ tannic acid equivalent/g DW and $10.9 \mathrm{mg} \mathrm{QE} / \mathrm{g} \mathrm{DW}$, respectively. Also, they found $\mathrm{IC}_{50}$ of $A$. millefolium as $854.1 \mu \mathrm{g} / \mathrm{mL}$ showing lower antioxidant activity than our result $\left(\mathrm{IC}_{50}=26.9 \mu \mathrm{g} / \mathrm{mL}\right)$ (AFSHARI \& al [42]). Conversely, CANDAN \& al [43] determined the $\mathrm{IC}_{50}$ of A. millefolium as $45.60 \mu \mathrm{g} / \mathrm{mL}$ that is very close to our result.

Higher total phenolic content (222.64 and $190.21 \mathrm{mg}$ $\mathrm{GAE} / \mathrm{g}$, respectively) and antioxidant capacity $\left(\mathrm{IC}_{50}\right.$ as $<12.5 \mu \mathrm{g} / \mathrm{mL}$ and $18.9 \mu \mathrm{g} / \mathrm{mL}$, respectively) were obtained for $P$. laciniata and $P$. vulgaris in our study than previous studies. For example, ŞAHIN \& al [56] showed that total phenolic content of $P$. laciniata and $P$. vulgaris were 93.4 and $97 \mathrm{mg}$ GAE/g dried plant, respectively. AHN \& al. [57] also reported that $P$. vulgaris had $\mathrm{IC}_{50}$ as $50.35 \mu \mathrm{g} / \mathrm{mL}$ and total phenolic content as $90.53 \mathrm{mg} \mathrm{GAE} / \mathrm{g}$.

CORREIA \& al. [58] determined IC $_{50}$ value of aqueous alcoholic extract of $A$. eupatoria as $18.12 \mu \mathrm{g} / \mathrm{mL}$ and total phenol as $15.78 \%$ that is to say lower antioxidant capacity and phenolic content than our study $(<12.5 \mu \mathrm{g} / \mathrm{mL}$ and $26 \%$ total phenol, respectively) (Table 3 and 4 ). Also, SANTOS \& al. [59] indicated $\mathrm{IC}_{50}$ value of $A$. eupatoria infusion as $12.8 \mu \mathrm{g} / \mathrm{mL}$. MURUZOVIĆ \& al [45] indicated total phenol and flavonoid content of $A$. eupatoria as $123.9 \mathrm{mg}$ GAE/g extract and $46.5 \mathrm{mg} \mathrm{RE} / \mathrm{g}$ extract, respectively and they obtained $59.59 \%$ inhibition of DPPH at $31.25 \mu \mathrm{g} / \mathrm{mL}$ that means lower total phenol, flavonoid 
and antioxidant capacity than our results (260.97 $\mathrm{mg} \mathrm{GAE} / \mathrm{g}$, $264.76 \mathrm{mg} \mathrm{CE} / \mathrm{g}$ and $\mathrm{IC}_{50}<12.5 \mu \mathrm{g} / \mathrm{mL}$, respectively)

$\mathrm{IC}_{50}$ value and total phenolic content of $V$. officinalis aerial part containing stem, leaves and flowers were $33.1 \mu \mathrm{g} / \mathrm{mL}, 10.2 \mathrm{~g} \mathrm{GAE} \%$ and $28.0 \mathrm{~g} \mathrm{CAE} \%$ in our study (Table 3 and 4). In one study it was found that $V$. officinalis aerial part had $\mathrm{IC}_{50}$ value as $69.58 \mu \mathrm{g} / \mathrm{mL}$ (LOPEZ \& al [52]). Hydroalcoholic extract of $V$. officinalis aerial part was investigated by REHECHO \& al [60]. $\mathrm{IC}_{50}$ value, total phenolic and flavonoid contents were recorded as $1.25 \mathrm{~g}$ GAE \%, $0.76 \mathrm{~g} \mathrm{RE} \%$ and $21.04 \mu \mathrm{g} / \mathrm{mL}$, respectively. KHALAF \& al [61] indicated moderate antioxidant potential of $V$. officinalis leaves $\left(\mathrm{IC}_{50}=23.63 \mu \mathrm{g} / \mathrm{mL}\right.$ ) and total phenolic content as $652.5 \mathrm{mg}$ GAE $\%$.

Strong radical scavenging capacity of $P$. comosa was revealed for the first time with this study. Correlation was not observed between antioxidant activity and total phenolflavonoid content for P. comosa (Table 3 and 4).

\section{HPLC Analysis}

Results obtained from the HPLC-DAD analysis presented that rosmarinic acid was the most dominant compound in $P$. laciniata and A. eupatoria. Rosmarinic acid was proved to have strong antioxidant activity (HOLZMANNOVÁ \& al [62]). Strong antioxidant potency of them may be related to high content of rosmarinic acid in the extract. In addition to rosmarinic acid, A. eupatoria contained rutin, apigenin, kaempferol and quercetin in the order of decreasing phenolic quantity (Table 5). KUBÍNOVÁ \& al [63] demonstrated HPLC profile of the aqueous extract of $A$. eupatoria containing quercetin, apigenin, luteolin and kaempferol glycosides.

Table 5. Quantitative analysis of tested plant extracts by HPLC-DAD. Data were presented as a mean number of phenol amount \pm standard error (SE). RT: Retention time.

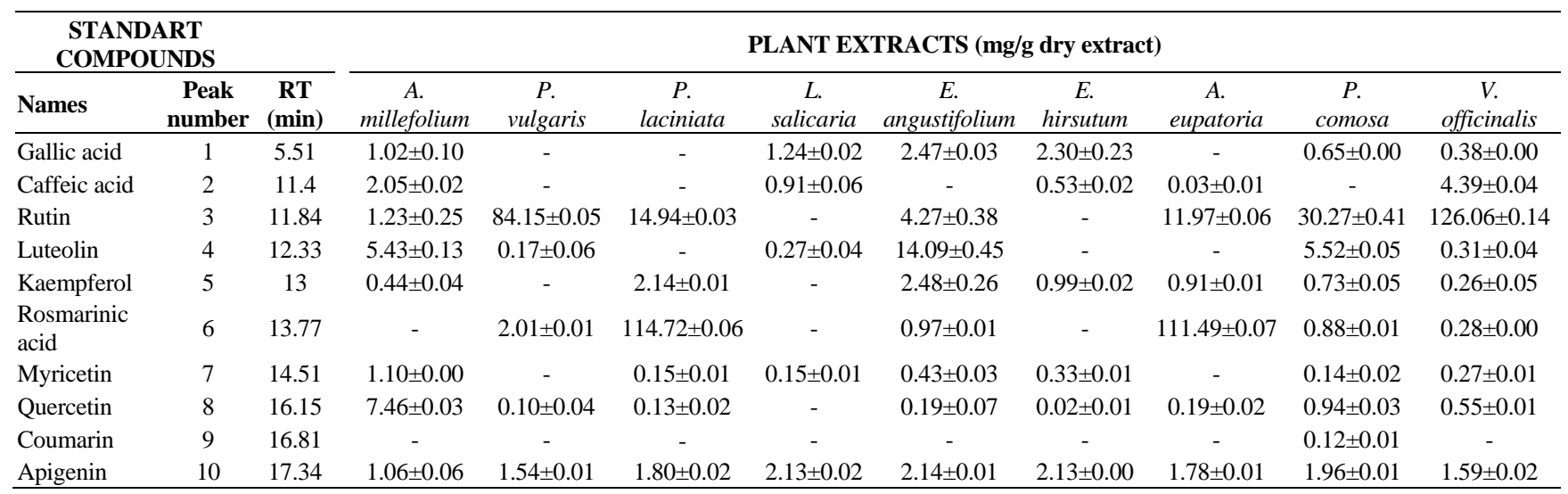

$V$. officinalis and $P$. vulgaris were the best rutin source. In consistent with the result of ŞAHIN \& al [56], $P$. laciniata and $P$. vulgaris were the best sources of rosmarinic acid and rutin, respectively. Also, FENG \& al. [64] presented that main compounds in ethanol extract of $P$. vulgaris were caffeic acid, rosmarinic acid, rutin and quercetin, respectively. However, caffeic acid was not detected in our study (Table 5). Caffeic acid and apigenin were also abundant besides rutin in $V$. officinalis in our study (Table 5). In one record, hastatoside, verbenalin, luteolin, apigenin and verbascoside were identified as major components of $V$. officinalis in $50 \% \mathrm{MeOH}$ extract (CALVO \& al [65]).

Phenolic content of E. angustifolium followed the order of decreasing amount as luteolin, rutin, kaempferol, gallic acid, apigenin, rosmarinic acid, myricetin and quercetin (Table 5). Similar to our result, TÓTH \& al [49] reported that quercetin and kaempferol were dominant in E. angustifolium. Also, gallic acid, ellagic acid, quercetin and myricetin were found in high amount in ethanol extract of E. angustifolium (DENG \& al [50]). However, luteolin and rutin were found in high concentrations in E. angustifolium in our study (Table 5).
HPLC analysis for A. millefolium showed that phenolic content followed the decreasing order of quercetin, luteolic, caffeic acid and rutin (Table 5). BOBIS $\&$ al [41] identified rosmarinic acid, rutin, luteolin and caffeic acid with descending order in this plant. Rosmarinic acid was not identified in our study. 1,3-dicaffeoylquinic acid, rutin, apigenin, caffeic acid and luteolin were identified as the major phenols with HPLC analysis in A. millefolium by AFSHARI \& al [42].

It was found for the first time that $P$. comosa was the good source of rutin, luteolin and apigenin in the order of descending amount. Additionally, phenolic profile of L. salicaria was first revealed using tested phenolic standards with this study (Table 5).

\section{Conclusion}

Bioevaluation of the effectiveness of traditional medicines is gaining importance in recent years. Verification of traditional usage of medicinal plant opens new doors for the discovery of different drugs. In this study, nine different traditional plants were evaluated in terms of antibacterial and antioxidant potential relating with their 
traditional usages. Some traditional usages of L. salicaria, E. angustifolium, E. hirsutum and A. eupatoria were strongly confirmed with our antibacterial results. Furthermore, strong antioxidant potential of these plants scientifically justified the ethnobotanical records of them as antiinflammatory. On the other hand, folkloric usages of $P$. laciniata as a remedy in skin diseases, wounds and cough were not proved with our tested 10 pathogenic bacteria. The best antioxidant activity was determined with L. salicaria, P. laciniata and E. angustifolium. Moreover, the highest total phenolic and flavonoid contents were obtained with E. hirsutum, A. millefolium and L. salicaria. The most remarkable plants in terms of antibacterial and antioxidant potentials were L. salicaria, E. hirsutum and E. angustifolium when evaluated together. These plants may be appropriate natural sources for drugs that can be used for the treatment of infections and also they can be a source of food additives as antioxidant ingredient to prevent many diseases.

\section{Acknowledgements}

This study was supported by Bolu Abant Izzet Baysal University Research Foundation (BAP 05.03.01.219), Turkey.

\section{Conflict of Interest}

The authors declare that they have no conflict of interest.

\section{References}

1. MUKHERJEE PK, BAHADUR S, CHAUDHARY SK, KAR A, MUKHERJEE K. Quality related safety issue-evidence-based validation of herbal medicine farm to pharma. In: Mukherjee PK. Evidence-based validation of herbal medicine. Amsterdam: Elsevier, 2015: 1.

2. KÜLTÜR Ş. Medicinal plants used in Kırklareli province (Turkey). J Ethnopharmacol 2007; 111: 341-364.

3. ALTUNDAG E, OZTURK M. Ethnomedicinal studies on the plant resources of east Anatolia, Turkey. Procedia-Soc Behav Sci 2011; 19: 756-777.

4. POLAT R, SATIL F. An ethnobotanical survey of medicinal plants in Edremit Gulf (Balikesir-Turkey). J Ethnopharmacol 2012; 139: 626-641.

5. GULER B, MANAV E, UGURLU E. Medicinal plants used by traditional healers in Bozuyuk (BilecikTurkey). J Ethnopharmacol 2015; 173: 39-47.

6. GUARINO C, DE SIMONE L, SANTORO S. Ethnobotanical study of the Sannio area, Campania, southern Italy, Ethnobot Res Appl, 6 (2008) 255-317.

7. KOYUNCU O, YAYLACI O, ÖZTÜRK D, POTOGLU ERKARA I, SAVAROGLU $F$ et al. Risk categories and ethnobotanical features of the Lamiaceae taxa growing naturally in Osmaneli
(Bilecik/Turkey) and environs, Biodivers Conserv, 3 (2010) 31-45.

8. ŠARIĆ-KUNDALIĆ B, DOBEŠ C, KLATTEASSELMEYER V, SAUKEL J, Ethnobotanical survey of traditionally used plants in human therapy of east, north and north-east Bosnia and Herzegovina, J Ethnopharmacol, 133 (2011) 1051-1076.

9. KUJAWSKA M, KLEPACKI P, ŁUCZAJ Ł. Fischer's plants in folk beliefs and customs: a previously unknown contribution to the ethnobotany of the Polish-Lithuanian-Belarusian borderland, $J$ Ethnobiol Ethnomed, 13 (2017) 1-15.

10. REDZIC S. The ecological aspect of ethnobotany and ethnopharmacology of population in Bosnia and Herzegovina, Coll Antropol, 31 (2007) 869-890.

11. MUMCU Ü \& KORKMAZ H. Ethnobotanical uses of alien and native plant species of Yeşilırmak Delta, Samsun, Turkey, Acta Biol Turc, 31(2018) 102-113.

12. REDZIC S. Wild medicinal plants and their usage in traditional human therapy (Southern Bosnia and Herzegovina, W. Balkan), J Med Plant Res, 4 (2010) 1003-1027.

13. TITA I, MOGOSANU GD, TITA MG. Ethnobotanical inventory of medicinal plants from the South-West of Romania, Farmacia, 57 (2009) 141-156.

14. DI NOVELLA R, DI NOVELLA N, DE MARTINO L, MANCINI E, DE FEO V. Traditional plant use in the National Park of Cilento and Vallo di Diano, Campania, Southern, Italy, J Ethnopharmacol, 145 (2013) 328-342.

15. PIWOWARSKI JP, GRANICA S, KISS AK. Lythrum salicaria L.-Underestimated medicinal plant from European traditional medicine. A review, $J$ Ethnopharmacol, 170 (2015) 226-250.

16. AL-QURA'N S. Folk medicinal qualities of aquatic plants in Jordan, J Herbs Spices Med Plants, 13 (2008) 95-106.

17. ARNOLD N, BAYDOUN S, CHALAK L, RAUS T. A contribution to the flora and ethnobotanical knowledge of Mount Hermon, Lebanon, Fl Medit, 25 (2015) 13-55.

18. KORKMAZ M, KARAKUŞ S, SELVI S, ÇAKILCIOĞLU U. Traditional knowledge on wild plants in Üzümlü (Erzincan-Turkey), Indian J Tradit Know,15 (2016) 538-545.

19. MENALE B, AMATO G, DI PRISCO C, MUOIO R. Traditional uses of plants in North-Western Molise (Central Italy), Delpinoa, 48 (2006) 29-36.

20. BALLABH B \& CHAURASIA OP. Medicinal plants of cold desert Ladakh used in the treatment of stomach disorders, Indian J Tradit Know, 8 (2009) 185-190.

21. CANSARAN A \& KAYA ÖF. Contributions of the ethnobotanical investigation carried out in Amasya district of Turkey (Amasya-Center, Bağlarüstü, Boğaköy and Vermiş villages; Yassıçal and Ziyaret towns), Biodivers Conserv, 3 (2010) 97-116. 
22. BARTFAY WJ, BARTFAY E \& JOHNSON JG. Gram-negative and gram-positive antibacterial properties of the whole plant extract of willow herb (Epilobium angustifolium), Biol Res Nurs, 14 (2012) 85-89.

23. KORKMAZ M. Kelkit (Gümüşhane) aktarlarında satılan tıbbi bitkilerin etnobotanik özellikleri, Süleyman Demirel Üniversitesi Fen Bilimleri Enstitüsü Dergisi, 18 (2014) 60-80.

24. AKAN H \& BAKIR Y. Kâhta (Adıyaman) merkezi ve Narince köyü'nün etnobotanik açıdan araştırılması, BEÜ Fen Bilimleri Dergisi, 4 (2015) 219-248.

25. KORKMAZ M, KARAKUŞ S, ÖZÇELIK H \& SELVI $\mathrm{S}$, An ethnobotanical study on medicinal plants in Erzincan, Turkey. Indian J Tradit Know, 15 (2016) 192-202.

26. SETZER W. The phytochemistry of Cherokee aromatic medicinal plants, Medicines, 5 (2018) 121.

27. YATOO MI, DIMRI U, GOPALAKRISHNAN A, KARTHIK K, GOPI $M$ et al. Beneficial health applications and medicinal values of Pedicularis plants: A review, Biomed Pharmacother, 95 (2017) 1301-1313.

28. ALTUNDAĞ ÇAKIR E. Traditional knowledge of wild edible plants of Iğdır Province (East Anatolia, Turkey), Acta Soc Bot Pol, 86 (2017) 3568.

29. CAKILCIOGLU U \& TURKOGLU I. An ethnobotanical survey of medicinal plants in Sivrice (Elazığ-Turkey), J Ethnopharmacol, 132 (2010) 165-175.

30. CAVERO RY \& CALVO MI. Medicinal plants used for respiratory affections in Navarra and their pharmacological validation, J Ethnopharmacol, 158 (2014) 216-220.

31. OZTURK M, ALTUNDAĞ E, IBADULLAYEVA SJ, ALTAY V, ASLANIPOUR B. A comparative analysis of medicinal and aromatic plants used in the traditional medicine of Iğdır (Turkey), Nakhchivan (Azerbaijan), and Tabriz (İran), Pak J Bot, 50 (2018) 337-343.

32. BONET MÀ, PARADA M, SELGA A, VALLES J. Studies on pharmaceutical ethnobotany in the regions of L'Alt Emporda and Les Guilleries (Catalonia, Iberian Peninsula), J Ethnopharmacol, 68 (1999) 145-168.

33. DAVIS PH. Flora of Turkey and the East Aegean Islands, Vols. 1-9, (Edinburgh University Press, Edinburgh), 1965-1985.

34. YILDIRIM AB, GUNER B, KARAKAS FP, TURKER AU. Evaluation of antibacterial, antitumor, antioxidant activities and phenolic constituents of fieldgrown and in vitro-grown Lysimachia vulgaris L, Afr J Tradit Complement Altern Med, 14 (2017) 177-187.

35. RAUHA JP, REMES S, HEINONEN M, HOPIA A, KÄHKÖNEN M. Antimicrobial effects of Finnish plant extracts containing flavonoids and other phenolic compounds, Int J Food Microbiol, 56 (2000) 3-12.
36. KUNDUHOGLU B, PILATIN S, CALISKAN F. Antimicrobial screening of some medicinal plants collected from Eskisehir, Turkey, Fresenius Environ Bull, 20 (2011) 945-952.

37. PIRVU L, HLEVCA C, NICU I, BUBUEANU C. Comparative studies on analytical, antioxidant, and antimicrobial activities of a series of vegetal extracts prepared from eight plant species growing in Romania, J Planar Chromat-Modern TLC, 27 (2014) 346-356.

38. BECKER H, SCHER JM, SPEAKMAN JB, ZAPP J. Bioactivity guided isolation of antimicrobial compounds from Lythrum salicaria, Fitoterapia, 76 (2005) 580-584.

39. KIRBAG S, ZENGIN F, KURSAT M. Antimicrobial activities of extracts of some plants, Pak J Bot, 41 (2009) 2067-2070.

40. FAIKU F, HAZIRI A, MEHMETI I, MEHMETI A, HOTI G. In vitro antibacterial activity of different solvent extracts of Achillea millefolium (L.) growing wild in Kosovo, Fresenius Environ Bull, 27 (2018) 3878-3883.

41. BOBIS O, DEZMIREAN DS, TOMOS L, CHIRILA F, MARGHITAS LA. Influence of phytochemical profile on antibacterial activity of different medicinal plants against gram-positive and gram-negative bacteria, App Biochem Microbiol, 51 (2015) 113-118.

42. AFSHARI M, RAHIMMALEK M, MIROLIAEI M. Variation in polyphenolic profiles, antioxidant and antimicrobial activity of different Achillea Species as natural sources of antiglycative compounds, Chem Biodivers, 15 (2018) e1800075.

43. CANDAN F, UNLU M, TEPE B, DAFERERA D, POLISSIOU $\mathrm{M}$ et al. Antioxidant and antimicrobial activity of the essential oil and methanol extracts of Achillea millefolium subsp. millefolium Afan. (Asteraceae), J Ethnopharmacol, 87 (2003) 215-220.

44. SHAHBAZI Y, ZADEH MS. In vitro assessment of antimicrobial efficacy of alcoholic extract of Achillea millefolium in comparison with penicillin derivatives, $J$ Anim Vet Adv, 7 (2008) 508-511.

45. MURUZOVIĆ MŽ, MLADENOVIĆ KG, STEFANOVIĆ OD, VASIĆ SM, ČOMIĆ LR. Extracts of Agrimonia eupatoria L. as sources of biologically active compounds and evaluation of their antioxidant, antimicrobial, and antibiofilm activities, J Food Drug Anal, 24 (2016) 539-547.

46. SISAY M, BUSSA N, GASHAW T, MENGISTU G. Investigating in vitro antibacterial activities of medicinal plants having folkloric repute in Ethiopian traditional medicine, J Evid Based Integr Med, 24 (2019) 1-9.

47. AHMED D, AHMED QASIM K, ASHRAF CM, MAAB H. Verbena officinalis a herb with promising broad spectrum antimicrobial potential, Cogent Chem, 3 (2017) 1-11. 
48. HUSSAIN T, TAN B, YIN Y, BLACHIER F, TOSSOU MC et al. Oxidative stress and inflammation: what polyphenols can do for us?, Oxid Med Cell Longev, 2016 (2016) 1-9.

49. TÓTH BH, BLAZICS B, KÉRY Á. Polyphenol composition and antioxidant capacity of Epilobium species, J Pharm Biomed Anal, 49 (2009) 26-31.

50. DENG LQ, ZHOU SY, MAO JX, LIU S, LAN XZ et al. HPLC-ESI-MS/MS analysis of phenolics and in vitro antioxidant activity of Epilobium angustifolium L, Nat Prod Res, 32 (2018) 1432-1435.

51. MANAYI A, KHANAVI M, SAIEDNIA S, AZIZI E, MAHMOODPOUR MR et al. Biological activity and microscopic characterization of Lythrum salicaria $\mathrm{L}$, DARU J Pharm Sci, 21 (2013) 1-7.

52. LOPEZ V, AKERRETA S, CASANOVA E, GARCÍA-MINA J, CAVERO R et al. Screening of Spanish medicinal plants for antioxidant and antifungal activities, Pharm Biol, 46 (2008) 602-609.

53. TUNALIER Z, KOŞAR M, KÜPELI E, ÇALIŞ İ, BAŞER KHC. Antioxidant, anti-inflammatory, antinociceptive activities and composition of Lythrum salicaria L. extracts, J Ethnopharmacol, 110 (2007) 539-547.

54. WOJDYŁO A, OSZMIAŃSKI J, CZEMERYS R. Antioxidant activity and phenolic compounds in 32 selected herbs, Food Chem, 105 (2007) 940-949.

55. HUMADI SS, ISTUDOR V. Lythrum salicaria (purple loosestrife), Medicinal use, extraction and identification of its total phenolic compounds, Farmacia, 57 (2009) 192-200.

56. ŞAHIN S, ARI F, DEMIR C, ULUKAYA E. Isolation of major phenolic compounds from the extracts of Prunella L. species grown in Turkey and their antioxidant and cytotoxic activities, J Food Biochem, 38 (2014) 248-257.

57. AHN EY, LEE YJ, PARK J, CHUN P, PARK Y. Antioxidant potential of Artemisia capillaris, Portulaca oleracea, and Prunella vulgaris extracts for biofabrication of gold nanoparticles and cytotoxicity assessment, Nanoscale Res Lett, 13 (2018) 1-14.

58. CORREIA H, GONZÁLEZ-PARAMÁS A, AMARAL MT, SANTOS-BUELGA C, BATISTA MT, Polyphenolic profile characterization of Agrimonia eupatoria L by HPLC with different detection devices, Biomed Chromatogr, 20 (2006) 88-94.

59. SANTOS TN, COSTA G, FERREIRA JP, LIBERAL J, FRANCISCO V et al. Antioxidant, anti-inflammatory, and analgesic activities of Agrimonia eupatoria L. infusion, Evid Based Complement Alternat Med, 2017 (2017), 1-13.

60. REHECHO S, HIDALGO O, DE CIRANO MGI, NAVARRO I, ASTIASARÁN I et al. Chemical composition, mineral content and antioxidant activity of Verbena officinalis L, LWT-Food Sci Technol, 44 (2011) 875-882.

61. KHALAF NA, NAIK RR, SHAKYA AK, SHALAN N, AL-OTHMAN A. Antioxidant, anti-inflammatory and anti-diarrheal activity of ethanolic extract of medicinal plants grown in Jordan and Palestine, Oriental J Chem, 31 (2015) 1923-1928.

62. HOLZMANNOVÁ V. Rosmarinic acid and its biological activity, Chem Listy, 90 (1996) 486-496.

63. KUBÍNOVÁ R, ŠVAJDLENKA E, JANKOVSKÁ D. Anticholinesterase, antioxidant activity and phytochemical investigation into aqueous extracts from five species of Agrimonia genus, Nat Prod Res, 30 (2016) 1174-1177.

64. FENG L, JIA X, ZHU MM, CHEN Y, SHI F. Antioxidant activities of total phenols of Prunella vulgaris $\mathrm{L}$. in vitro and in tumor-bearing mice, Molecules, 15 (2010) 9145-9156.

65. CALVO MI, SAN JULIAN A, FERNANDEZ M. Identification of the major compounds in extracts of Verbena officinalis L.(Verbenaceae) by HPLC with post-column derivatization, Chromatographia, 46 (1997) 241-244. 